\title{
ANALISIS TINGKAT KESEHATAN BANK DENGAN METODE RGEC (Studi Kasus PT. Bank BNI Tbk)
}

\author{
Khayatun Nufus*), Awaluddin Muchtar ${ }^{\star *}$, Fani Triyanto $\left.{ }^{* *}\right)$ \\ Email : nufus_awal@yahoo.co.id
}

\begin{abstract}
ABSTRAK
Analisis Tingkat Kesehatan Bank Dengan Metode RGEC Studi Kasus PT.Bank BNI (Persero) Tbk. Penelitian ini bertujuan untuk mengetahui bagaimana tingkat kesehatan PT Bank Negara Indonesia (Persero) Tbk. Penelitian ini diukur menggunakan pendekatan RGEC (Risk Profile, Good Corporate Governance, Earnings, Capital) pada tahun 2013-2017. Jenis penelitian yang digunakan adalah jenis penelitian deskriptif dengan pendekatan kuantitatif pada Laporan Keuangan BNI. Variabel dan pengukuran pada penelitian ini terdiri dari faktor Risk Profile, faktor Good Corporate Governance, faktor Earnings, faktor Capital. Hasil analisis menunjukkan bahwa tingkat kesehatan BNI pada tahun 2013 sampai dengan 2017 yang diukur menggunakan pendekatan RGEC dapat dikatakan bank yang sehat. Faktor Risk Profile yang dinilai melalui NPL, LDR, Cash Ratio menggambarkan pengelolaan risiko yang telah dilaksanakan dengan baik. Faktor Good Corporate Governance BNI sudah memiliki dan menerapkan tata kelola perusahaan dengan sangat baik. Faktor Earnings atau Rentabilitas yang penilaiannya terdiri dari ROA mengalami kenaikan dan hal ini menandakan bertambahnya jumlah aset yang dimiliki BNI diikuti dengan bertambahnya keuntungan yang didapat oleh BNI. Dengan menggunakan indikator CAR, peneliti membuktikan bahwa BNI memiliki faktor Capital yang baik, yaitu diatas ketentuan Bank Indonesia sebesar 8\%.
\end{abstract}

Kata kunci: Tingkat Kesehatan Bank dan Metode RGEC

\begin{abstract}
BANK HEALTH LEVEL ANALYSIS WITH RGEC METHOD. Case Study of PT. Bank BNI (Persero) Tbk. Bank Health Level Analysis With RGEC Method Case Study Of PT. Bank BNI (Persero) Tbk. This study aims to find out how the health level of PT Bank Negara Indonesia (Persero) Tbk. This research was measured using the RGEC approach (Risk Profile, Good Corporate Governance, Earnings, Capital) in 2013-2017. The type of research used is descriptive research with a quantitative approach to the BNI Financial Report. The variables and measurements in this study consisted of Risk Profile factors, Good Corporate Governance factors, Earnings factors, Capital factors. The results of the analysis show that the health level of BNI from 2013 to 2017 measured using the RGEC approach can be said to be a healthy bank. Risk Profile factors assessed through NPL, LDR, Cash Ratio illustrate the risk management that has been implemented properly. Factor of Good Corporate Governance BNI already has and implements corporate governance very well. Earnings Factors or Rentability whose valuation consists of ROA has increased and this indicates an increase in the number of assets owned by $B N I$ followed by the increase in profits obtained by BNI. By using the CAR indicator, the researcher proves that BNI has a good Capital factor, which is above the Bank Indonesia regulation of $8 \%$.
\end{abstract}

Keywords: Bank Soundness and RGEC Method

*) Dosen Universitas Pamulang

${ }^{* *}$ ) Dosen Universitas Pamulang

***) Mahasiswa MM Universitas Pamulang 


\section{PENDAHULUAN}

\section{A. Latar Belakang}

Lembaga keuangan merupakan aset yang sangat penting dalam pembangunan perekonomian suatu negara. Di Indonesia, perkembangan perekonomian tidak bisa dilepaskan dari besarnya peranan lembaga keuangan. Secara umum, lembaga keuangan adalah setiap perusahaan yang bergerak di bidang keuangan, di mana kegiatannya menghimpun dana atau menyalurkan dana atau kedua-duanya menghimpun dan menyalurkan dana (Kasmir, 2012:12).

Salah satu indikator utama yang dijadikan dasar penilaian kesehatan adalah laporan keuangan bank yang menunjukkan kondisi keuangan bank secara keseluruhan. Dalam kasmir (2011) Laporan keuangan bank yang menunjukkan kondisi keuangan bank secara keseluruhan. Dari laporan keuangan akan terbaca bagaimana kondisi bank yang sesungguhnya, termasuk kelemahan dan kekuatan yang dimiliki.

Bank Indonesia melakukan langkah strategis dalam mendorong penerapan manajemen risiko bank yang tertuang dalam Peraturan Bank Indonesia No. 13/1/PBI/2011 tentang Penilaian Tingkat Kesehatan Bank Umum dengan Risk Profile (Risiko Profil), Good Corporate Governance (GCG), Earnings (Rentabilitas), dan Capital (Permodalan) yang selanjutnya disebut dengan metode RGEC. Pedoman perhitungan selanjutnya diatur dalam Surat Edaran Bank Indonesia No. 13/24/DPNP tanggal 25 Oktober 2011 perihal Penilaian Tingkat Kesehatan Bank Umum yang mewajibkan bank umum untuk melakukan penilaian sendiri (Self Assesment) tingkat kesehatan bank dengan menggunakan metode RGEC.

Dalam metode RGEC, kualitas manajemen merupakan pilar penting. Kualitas manajemen yang baik dapat diketahui dari hasil penerapan manajemen risiko dan RGEC dibank tersebut. Dengan kata lain, penilaian faktor rentabilitas dan permodalan hanya merupakan dampak dari strategi yang dilakukan oleh manajemen (Permana, 2012). Metode RGEC ini berlaku secara efektif sejak tanggal 1 Januari 2012 yaitu untuk penilaian tingkat kesehatan bank periode yang berakhir 31 Desember 2011 dan sekaligus mencabut PBI No. 6/10/PBI/2004 tentang sistem Penilaian Tingkat Kesehatan Bank Umum dan SE BI No. 6/23/DPNP tanggal 31 Mei 2004 tentang Sistem Penilaian Tingkat Kesehatan Bank Umum dengan metode CAMELS (www.bi.go.id).

PT Bank Negara Indonesia (Persero), Tbk (selanjutnya disebut "BNl" atau "Bank") pada awalnya didirikan di Indonesia sebagai Bank sentral dengan nama "Bank Negara Indonesia" berdasarkan Peraturan Pemerintah Pengganti Undang-Undang No. 2 tahun 1946 tanggal 5 Juli 1946. Selanjutnya, berdasarkan Undang-Undang No. 17 tahun 1968, BNI ditetapkan menjadi "Bank Negara Indonesia 1946", dan statusnya menjadi Bank Umum Milik Negara. Selanjutnya, peran BNI sebagai Bank yang diberi mandat untuk memperbaiki ekonomi rakyat dan berpartisipasi dalam pembangunan nasional dikukuhkan oleh UU No. 17 tahun 1968 tentang Bank Negara Indonesia 1946.

BNI merupakan Bank BUMN (Badan Usaha Milik Negara) pertama yang menjadi perusahaan publik setelah mencatatkan sahamnya di Bursa Efek Jakarta dan Bursa Efek Surabaya pada tahun 1996. Untuk memperkuat struktur keuangan dan daya saingnya di tengah industri perbankan nasional, BNI melakukan sejumlah aksi korporasi, antara lain proses rekapitalisasi oleh Pemerintah di tahun 1999, divestasi 
saham Pemerintah di tahun 2007, dan penawaran umum saham terbatas di tahun 2010. Saat ini, $60 \%$ saham-saham BNI dimiliki oleh Pemerintah Republik Indonesia, sedangkan $40 \%$ sisanya dimiliki oleh masyarakat, baik individu maupun institusi, domestik dan asing. BNI kini tercatat sebagai Bank nasional terbesar ke-4 di Indonesia, dilihat dari total aset, total kredit maupun total dana pihak ketiga. Dalam memberikan layanan finansial secara terpadu, BNI didukung oleh sejumlah perusahaan anak, yakni Bank BNI Syariah, BNI Multifinance, BNI Sekuritas, BNI Life Insurance, dan BNI Remittance.

BNI menawarkan layanan penyimpanan dana maupun fasilitas pinjaman baik pada segmen korporasi, menengah, maupun kecil. Beberapa produk dan layanan terbaik telah disesuaikan dengan kebutuhan nasabah sejak kecil, remaja, dewasa, hingga pensiun.

Tabel 1.1 : Pra Data Bank BNI 2013-2017 (Dalam Jutaan Rupiah)

\begin{tabular}{|c|c|c|c|c|c|}
\hline & 2013 & 2014 & 2015 & 2016 & 2017 \\
\hline $\begin{array}{c}\text { Kredit } \\
\text { Bermasalah }\end{array}$ & $5,421,043$ & $5,436,740$ & $8,709,610$ & $11,644,275$ & $10,097,575$ \\
\hline Total Kredit & $250,637,843$ & $277,622,281$ & $326,105,149$ & $393,275,392$ & $441,313,566$ \\
\hline Dana pihak ketiga & 282,740 & 300,625 & 353,937 & 415,543 & 492,748 \\
\hline $\begin{array}{c}\text { Laba Sebelum } \\
\text { Pajak }\end{array}$ & $11,278,165$ & $13,524,310$ & $11,466,148$ & $14,302,905$ & $17,165,387$ \\
\hline Total Aset & $386,654,815$ & $416,573,708$ & $508,595,288$ & $603,031,880$ & $709,330,084$ \\
\hline Modal Bank & 43,563 & 50,352 & 73,799 & 84,278 & 95,307 \\
\hline ATMR & 251,142 & 268,430 & 329,343 & 378,716 & 450,706 \\
\hline GCG & PK 2 & PK 2 & PK 2 & PK 2 & PK 2 \\
\hline
\end{tabular}

Sumber : http://www.bni.co.id ( Data sudah diolah)

Berdasarkan uraian di atas, terlihat adanya variasi hasil penelitian yang berbedabeda sehingga menimbulkan research gap dan peneliti tertarik melakukan penelitian dengan topik sejenis. Adapun penelitian ini diberi judul ANALISIS TINGKAT KESEHATAN BANK DENGAN METODE RGEC (Studi Kasus PT. Bank BNI Persero Tbk)

\section{B. Identifikasi Masalah}

1. Kredit bermasalah mengalami peningkatan setiap tahunnya dari tahun 2013 hingga 2016.

2. Tingkat keuntungan laba yang diperoleh sempat mengalami penurunan karena margin dari penyaluran kredit yang lemah, ditambah masih tingginya kredit bermasalah terhadap pengembalian kredit.

3. Belum diterapkannya peraturan Bank Indonesia dalam perhitungan kinerja kesehatan Bank disemua Perbankan maka banyak terjadi kesalahan dalam pelaksanaannya .

4. Persaingan Bank dalam memperoleh nasabah yang begitu ketat membuat perbankan menjadi sulit mendapatkan modal dan menawarkan produknya.

5. Belum maksimalnya mengalokasi dana kredit terhadap masyarakat. 


\section{Pembatasan Masalah}

1. Untuk faktor Risk Profile pada penelitian ini yang digunakan adalah risiko kredit yaitu dengan menghitung NPL (Non Performing Loan) dan risiko likuiditas yaitu dengan menghitung LDR (Loan to Deposit Ratio). Untuk faktor Good Corporate Governance (GCG) diambil dari laporan tahunan (annual report) masing-masing bank yang melakukan self assessment terhadap pelaksanaan GCG. Sedangkan untuk faktor Earnings penilaian yang digunakan adalah rasio ROA (Return On Assets). Untuk faktor Capital pada penelitian ini yang digunakan adalah CAR (Capital Adequacy Ratio).

2. Data penelitian berupa laporan keuangan peiode 2013-2017.

\section{Perumusan Masalah}

Bersumber pada latar belakang, menunjukkan terdapat berbagai hasil penelitian yang tidak konsisten, sehingga peneliti merumuskan masalah sebagai berikut :

1. Bagaimana Penilaian Tingkat Kesehatan Bank pada PT Bank Negara Indonesia (Persero ) Tbk ditinjau dari Risk Profile pada tahun 2013-2017 ?

2. Bagaimana Penilaian Tingkat Kesehatan Bank pada PT Bank Negara Indonesia (Persero) Tbk ditinjau dari Good Coorporate Governance pada tahun 2013-2017 ?

3. Bagaimana Penilaian Tingkat Kesehatan Bank pada PT Bank Negara Indonesia (Persero) Tbk ditinjau dari Earning pada tahun 2013-2017?

4. Bagaimana Penilaian Tingkat Kesehatan Bank pada PT Bank Negara Indonesia (Persero) Tbk ditinjau dari Capital pada tahun 2013-2017 ?

5. Bagaimana Penilaian Tingkat Kesehatan Bank pada PT Bank Negara Indonesia (Persero) Tbk ditinjau dari aspek RGEC pada tahun 2013-2017 ?

\section{TINJAUAN PUSTAKA}

\section{A. Kinerja Perbankan}

Penilaian kinerja perbankan dapat dilihat dari tingkat kesehatan bank yang bersangkutan. Kesehatan bank diartikan sebagai kemampuan suatu bank yang bersangkutan dalam menjalankan fungsinya sesuai peraturan yang ada. Kesehatan bank dapat diartikan sebagai kemampuan suatu bank untuk melakukan kegiatan operasional perusahaan secara normal dan mampu memenuhi semua kewajibannya dengan baik dengan cara-cara yang sesuai dengan peraturan perbankan yang berlaku. Kesehatan suatu bank dalam melaksanakan kegiatan perbankannya, meliputi kemampuan menghimpun dana dari masyarakat, dari lembaga lain, dan dari modal sendiri; kemampuan mengelola dana; kemampuan untuk menyalurkan dana ke masyarakat; kemampuan memenuhi kewajiban kepada masyarakat, karyawan, pemilik modal, dan pihak lain; serta pemenuhan peraturan perbankan yang berlaku.

Analisis kinerja perbankan dilakukan meliputi seluruh aspek, baik operasional maupun nonoperasional bank tersebut. Banyak metode yang dapat digunakan untuk mengetahui kinerja suatu bank yang juga lazim dianut oleh bank-bank di dunia, selain yang umum berlaku di Indonesia sesuai dengan ketentuan Bank Indonesia yang dikenal dengan "penilaian tingkat kesehatan bank". Penilaian tingkat kesehatan ini mencakup financial aspect serta non-financial aspect (Veitzhal Rivai dkk, 2007 : 699). 


\section{Peran Bank}

Menurut Totok Santoso dan Nuritomo (2014: 11-12) peran bank adalah sebagai berikut :

a. Pengalihan aset (Asset transmutation)

Bank akan memberikan pinjaman kepada pihak yang membutuhkan dana dalam jangka waktu tertentu yang telah disepakati. Sumber dana pinjaman tersebut diperoleh dari pemilik dana yaitu unit surplus yang jangka waktunya dapat diatur sesuai dengan pemilik dana. Dalam hal ini bank telah berperan sebagai pengalih aset yang likuid dari unit surplus (lenders) keapada unit defisit (borrowers).

b. Transaksi (Transaction)

Bank memberikan berbagai kemudahan kepada pelaku ekonomi untuk melakukan transaksi barang dan jasa dengan mengeluarkan produk-produk yang dapat memudahkan kegiatan transaksi diantaranya giro, tabungan, deposito, saham dan sebagainya.

c. Likuiditas (Liquidity)

Unit surplus dapat menempatkan dana yang dimilikinya dalam bentuk produkproduk berupa giro, tabungan, deposito dan sebagainya. Untuk kepentingan likuiditas para pemilik dana dapat menempatkan dananya sesuai dengan kebutuhan dan kepentingannya karena produk-produk tersebut mempunyai tingkat likuiditas yang berbeda-beda.

d. Efisiensi (Efficiency)

Adanya informasi yang tidak simetris antara peminjam dan investor menimbulkan masalah insentif, sehingga menimbulkan ketidakefisienan dan menambah biaya. Dengan adanya bank sebagai broker maka masalah tersebut dapat teratasi.

\section{Karakteristik Bank}

Menurut Taswan (2008: 2), lembaga perbankan mudah dikenali karena memiliki karakteristik umum sebagai berikut :

a. Bank merupakan lembaga perantara keuangan antara pihak- pihak yang memiliki kelebihan dana dengan pihak-pihak yang membutuhkan dana, serta berfungsi untuk memperlancar lalu lintas pembayaran dengan berpijak pada falsafah kepercayaan.

b. Sebagai lembaga kepercayaan, bank harus selalu menjaga likuiditasnya sehingga mampu memenuhi kewajiban yang harus segera dibayar.

c. Bank selalu dihadapkan pada dilema antara pemeliharaan likuiditas atau peningkatan earning power. Kedua hal ini berlawanan dalam mengelola dana perbankan. Yang artinya jika menginginkan likuiditas tinggi maka earning atau rentabilitas rendah dan sebaliknya.

d. Bank sebagai lembaga kepercayaan mempunyai kedudukan yang strategis untuk menunjang pembangunan nasional.

\section{Jenis Bank}

Menurut Totok Santoso dan Nuritomo (2014: 109-111) bank dibagi menjadi dua yaitu :

a. Bank umum adalah bank yang melaksanakan kegiatan usaha secara konvensional dan atau berdasarkan prinsip syariah yang dalam kegiatannya memberikan jasa dalam lalu lintas pembayaran. 
b. Bank perkreditan rakyat adalah bank yang melaksanakan kegiatan usahanya secara konvensional atau berdasarkan prinsip syariah yang dalam kegiatannya tidak memberikan jasa dalam lalu lintas pembayaran.

B. Faktor Penilaian Tingkat Kesehatan Bank

Faktor penilaian tingkat kesehatan bank yaitu RGEC : Pada PBI No. 13/1/PBI/2011 dan SE No. 13/ 24/ DPNP tanggal 25 Oktober 2011 yang menjadi indikator adalah:

1. Risk profile

Penilaian terhadap resiko terbagi menjadi 8 bagian yaitu:

a. Risiko kredit

Risiko pinjaman tidak kembali sesuai dengan kontrak, seperti penundaan, pengurangan pembayaran suku bunga dan pinjaman pokonya, atau tidak membayar pinjamannya sama sekali. Rasio kredit dihitung dengan menggunakan rasio Non Performing Loan:

$$
\mathrm{NPL}=\frac{\text { Kredit Bermasalah }}{\text { Total Kredit }} \times 100 \%
$$

b. Risiko pasar

Suatu risiko yang timbul karena menurunnya nilai suatu investasi karena pergerakan pada faktor-faktor pasar. Rasio pasar dihitung dengan menggunakan rasio Interest Rate Risk:

$$
I R R=\frac{R S A(\text { Rate Sensitive Assets })}{R S L(\text { Rate Sensitive Liabilities })} \times 100
$$

c. Risiko likuiditas

Risiko kekurangan likuiditas terjadi karena adanya rush-penarikan dana secara serentak yang dapat mengakibatkan kebangkrutan bank.

Rasio likuiditas dihitung dengan menggunakan rasio- rasio sebagai berikut:

1) Loan to Deposit Ratio (LDR)

$$
\text { LDR }=\frac{\text { Total Kredit }}{\text { Dana Pihak Ketiga }} \quad x 100
$$

2) Loan to Asset Ratio (LAR)

$$
\mathrm{LAR}=\frac{\text { Total Kredit }}{\text { Total Asset }} \quad x 100 \%
$$

3) Cash Ratio

$$
\text { Cash Ratio }=\frac{\text { Alat }- \text { alat Likuid yang dikuasai }}{\text { Dana Pihak Ketiga }} \quad x 100 \%
$$

d. Risiko opersional

Risiko kerugian yang diakibatkan oleh kegagalan atau tidak memadainya proses internal, manusia dan sistem, atau sebagai akibat dari kejadian eksternal. 
e. Risiko hukum Risiko dari ketidakpastian tindakan atau tuntutan atau ketidakpastian dari pelaksanaan atau interpretasi dari kontrak, hukum atau peraturan.

f. Risiko stratejik

Risiko yang disebabkan oleh adanya penetapan dan pelaksanaan strategi bank yang tidak tepat, pengambilan keputusan bisnis yang tidak tepat atau kurang responsifnya bank terhadap perubahan eksternal.

g. Risiko kepatuhan

Risiko yang disebabkan oleh ketidakpatuhan suatu bank untuk melaksanakan perundang-undangan dan ketentuan lain yang berlaku, dan.

h. Risiko reputasi

Risiko akibat menurunnya tingkat kepercayaan stakeholder yang bersumber dari persepsi negatif terhadap bank.

\section{Good Corporate Governance}

Good Corpotrate Governance (GCG) ditinjau dari sisi pemenuhan prinsip-prinsip GCG. GCG mencerminkan bagian manajemen dari CAMELS namun telah disempurnakan. Bank memperhitungkan dampak GCG perusahaan pada kinerja GCG bank dengan mempertimbangkan signifikan dan materialitas perusahaan anak dan atau signifikasi kelemahan GCG perusahaan anak.

\section{a. Earning}

Earning adalah salah satu penilaian kesehatan bank dari sisi rentabilitas. Indikator penilaian rentabilitas adalah ROA (Return On Assets), ROE (Return On Equity), NIM (Net Interest Margin), dan BOPO (Beban Operasional Terhadap Pendapatan Operasional) komponen laba actual terhadap proyeksi anggaran dan kemampuan komponen laba dalam meningkatkan permodalan. Karakteristik bank dari sisi rentabilitas adalah kinerja bank dalam menghasilkan laba, kestabilan komponen-komponen yang mendukung core earning, dan kemampuan laba dalam meningkatkan permodalan dan prospek laba di masa depan. Penilaian terhadap faktor earnings didasarkan pada rasio yaitu:

1) Return on Assets (ROA)

2) Return On Equity (ROE)

$$
\mathrm{ROA}=\frac{\text { Laba Sebelum Pajak }}{\text { Rata }- \text { Rata Total Aset }} \quad \times 100 \%
$$

$$
\mathrm{ROE}=\frac{\text { Laba Sebelum Pajak }}{\text { Rata }- \text { Rata Modal Inti }} \quad \times 100 \%
$$

3) Net Interest Margin (NIM)

$$
\mathrm{NIM}=\frac{\text { Pendapatan Bunga Bersih }}{\text { Rata }- \text { Rata Aktiva Produktif }} \times 100 \%
$$

4) Beban Operasional Terhadap Pendapatan Operasional (BOPO)

$$
\text { BOPO }=\frac{\text { Beban Operasional }}{\text { Pendapatan Operasional }} \times 100 \%
$$




\section{b. Capital}

Capital / permodalan memiliki indicator antara lain rasio kecukupan modal dan kecukupan modal bank untuk mengantisipasi potensi kerugian sesuai profil resiko, yang disertai dengan pengelolaan permodalan yang sangat kuat sesuai dengan karakteristik, skala usaha dan kompleksitas usaha bank. Rasio kecukupan modal :

$$
\mathrm{CAR}=\frac{\text { Modal }}{\text { ATMR }} \times 100 \%
$$

\section{Metode (pendekatan RGEC)}

Berdasarkan peraturan Bank Indonesia No.13/1/PBI/2011 tentang Penilaian Tingkat Kesehatan Bank Umum, Bank Indonesia telah menetapkan sistem penilaian Tingkat Kesehatan Bank berbasis risiko menggantikan penilaian CAMELS yang dulunya diatur dalam PBI No.6/10/PBI/2004. Pedoman perhitungan selengkapnya diatur dalam Surat Edaran (SE) Bank Indonesia No/13/24/DPNP tanggal 25 Oktober 2011 tentang Penilaian Tingkat Kesehatan Bank Umum. Tahap- tahap penilaian dalam metode RGEC boleh disebut model penilaian kesehatan bank dengan sarat manajemen risiko. Apabila CAMELS adalah penilaian terhadap Capital, Asset Quality, Management, Earning, Liquidity \& Sensitivity to Market Risk, dalam penilaian pendekatan RGEC menurut Peraturan Bank Indonesia No. 13/1/PBI/2011 Pasal 7 faktor-faktor penilaiannya adalah :

\section{Risk Profile (Profil Risiko)}

Peraturan Bank Indonesia No.13/1/PBI/2011 Pasal 7 ayat 1 penilaian terhadap faktor profil risiko sebagaimana dimaksud dalam pasal 6 huruf a merupakan penilaian terhadap risiko inheren dan kualitas penerapan manajemen risiko dalam operasional Bank yang dilakukan terhadap 8 (delapan) risiko yaitu risiko kredit, risiko pasar, risiko likuiditas, risiko operasional, risiko hukum, risiko stratejik, risiko kepatuhan, risiko reputasi. Penelitian ini mengukur faktor Risk Profile dengan menggunakan 3 indikator yaitu faktor risiko kredit dengan menggunakan rumus Non Performing Loan (NPL), risiko pasar dengan menggunakan rumus Interest Rate Risk (IRR), dan risiko likuiditas dengan menggunakan rumus Loan to Deposit Ratio (LDR), Loan to Asset Ratio (LAR) dan Cash ratio.

\section{Good Corporate Governance (GCG)}

Penilaian terhadap faktor GCG dalam pendekatan RGEC didasarkan ke dalam tiga aspek utama yaitu, governance structure, governance process, dan governance output. Berdasarkan ketetapan Bank Indonesia yang disajikan dalam Laporan Pengawasan Bank (2012:36).

Governance structure mencakup pelaksanaan tugas dan tanggung jawab Dewan Komisaris dan Dewan Direksi serta kelengkapan dan pelaksanaan tugas komite. Governance process mencakup fungsi kepatuhan bank, penanganan benturan kepentingan, penerapan fungsi audit intern dan ekstern, penerapan manajemen risiko termasuk sistem pengendalian intern, penyediaan dana kepada pihak terkait dan dana besar, serta rencana strategis bank. Aspek terakhir governance output mencakup transaparansi kondisi keuangan dan non keuangan, laporan pelaksanaan GCG yang 
memenuhi prinsip Transparancy, Accountability, Responsibility, Indepedency, dan Fairness (TARIF)".

Implementasi Good Corporate Governance (selanjutnya disingkat "GCG") di BNI bertujuan untuk menciptakan kinerja yang unggul dan menambah nilai ekonomi bagi pemegang saham dan pemangku kepentingan lainnya, sekaligus menjamin Perseroan beroperasi dengan menaati peraturan perundangan-undangan yang berlaku, etika bisnis, Kode Etik BNI, serta prinsip-prinsip pengelolaan bank yang sehat.

\section{METODE PENELITIAN}

\section{A. Jenis Penelitian}

Penelitian ini merupakan penelitian deskriptif kuantitatif yaitu suatu metode penelitian yang ditujukan untuk menggambarkan fenomena-fenomena yang berlangsung saat ini atau pada saat lampau. Penelitian ini akan dilakukan dengan mengumpulkan data - data sesuai dengan ketentuan yang telah diatur dalam Peraturan Bank Indonesia No. 13/1/PBI/2011 dan SE No. 13/ 24/ DPNP tanggal 25 Oktober 2011.

\section{B. Metode Pengumpulan Data}

\section{Jenis dan Sumber Data}

Jenis data yang digunakan dalam penelitian ini adalah data dokumenter. Data dokumenter adalah data penelitian yang anatara lain berupa faktor, jurnal, surat-surat, hasil notulen rapat, memo, atau dalam bentuk laporan program. Berdasarkan sumber data penelitian ini menggunakan sumber data sekunder. Data sekunder adalah sumber data penelitian yang diperoleh peneliti seacara tidak langsung melalui media perantara. (Nur Indriantoro dan Supomo, 2013:147). Dalam penelitian ini data sekunder diperoleh dari laporan keuangan PT Bank Negara Indonesia (Persero) Tbk Periode 2013-2017.

\section{Teknik Analisis Data}

Teknik analisis data yang digunakan adalah teknik analisis laporan keuangan dengan menggunakan pendekatan Peraturan Bank Indonesia Nomor 13/1/PBI/2011 tentang Penilaian Tingkat Kesehatan Bank Umum, Bank Indonesia telah menetapkan sistem penilaian Tingkat Kesehatan Bank berbasis risiko menggantikan penilaian CAMELS. Penilaian terhadap faktor-faktor RGEC terdiri dari:

a. Profil Risiko (Risk Profile)

Penilaian terhadap risiko terbagi menjadi 8 bagian yaitu risiko kredit, risiko pasar, risiko likuiditas, risiko operasional, risiko hukum, risiko stratejik, risiko kepatuhan dan risiko reputasi. Dalam penelitian ini mengukur faktor risk profile dengan menggunakan 2 indikator yaitu faktor risiko kredit dengan menggunakan rumus NPL dan risiko likuiditas dengan rumus LDR, LAR, dan Cash Ratio.

Tabel 3.1:Kriteria Penetapan Peringkat Komponen Risiko Kredit \& Resiko Likuiditas

\begin{tabular}{|c|c|c|c|}
\hline Peringkat & Keterangan & Kriteria Risiko Kredit & Kriteria Risiko Likuiditas \\
\hline 1 & Sangat sehat & $<2 \%$ & $70 \%-<85 \%$ \\
\hline 2 & Sehat & $2 \%-3,5 \%$ & $60 \%-<70 \%$ \\
\hline 3 & Cukup sehat & $3,5 \%-5 \%$ & $85 \%-<100 \%$ \\
\hline 4 & Kurang sehat & $5 \%-8 \%$ & $100 \%-120 \%$ \\
\hline 5 & Tidak sehat & $>8 \%$ & $>120 \%-<60 \%$ \\
\hline
\end{tabular}

Sumber : Surat Edaran Bank Indonesia 
b. Good Corporate Governance

Good Corporate Governance (GCG) ditinjau dari sisi pemenuhan prinsip-prinsip GCG. GCG mencerminkan bagian manajemen dari CAMELS namun telah disempurnakan. Bank memperhitungkan dampak GCG perusahaan pada kinerja GCG bank dengan mempertimbangkan signifikan dan materialitas perusahaan anak dan atau signifikasi kelemahan GCG perusahaan anak.

Tabel 3.2 : Kriteria Penetapan Peringkat Komponen Good Corporate Governance

\begin{tabular}{|c|c|}
\hline Peringkat & Keterangan \\
\hline 1 & Sangat Baik \\
\hline 2 & Baik \\
\hline 3 & Cukup Baik \\
\hline 4 & Kurang Baik \\
\hline 5 & Tidak Baik \\
\hline \multicolumn{2}{|c|}{ Sumber : Surat Edaran Bank Indonesia } \\
\hline
\end{tabular}

c. Earnings (Rentabilitas)

Tabel 3.3 : Kriteria Penetapan Peringkat Komponen Rentabilitas (ROA)

\begin{tabular}{|l|l|l|}
\hline Peringkat & Keterangan & \multicolumn{1}{|c|}{ Kriteria } \\
\hline 1 & Sangat Sehat & $\begin{array}{l}\text { Perolehan laba sangat tinggi (rasio ROA } \\
\text { diatas 2\%) }\end{array}$ \\
\hline 2 & Sehat & $\begin{array}{l}\text { Perolehan laba tinggi (rasio ROA berkisar } \\
\text { antara 1,26\% sampai dengan 2\%) }\end{array}$ \\
\hline 3 & Cukup Sehat & $\begin{array}{l}\text { Perolehan laba cukup tinggi (rasio ROA } \\
\text { berkisar antara 0,51\% sampai dengan 1,25\%) }\end{array}$ \\
\hline 4 & Kurang Sehat & $\begin{array}{l}\text { Perolehan laba rendah atau cenderung } \\
\text { mengalami kerugian (ROA mengarah negatif, } \\
\text { rasio berkisar 0\% sampai dengan 0,5\%) }\end{array}$ \\
\hline 5 & Tidak Sehat & $\begin{array}{l}\text { Bank mengalami kerugian yang besar (ROA } \\
\text { negatif, rasio dibawah 0\%) }\end{array}$ \\
\hline
\end{tabular}

Sumber : Surat Edaran Bank Indonesia

d. Capital

Capital atau permodalan yaitu metode penilaian bank berdasarkan permodalan yang dimiliki bank dengan menggunakan rasio Capital Adequacy Ratio (CAR).

Tabel 3.4 : Kriteria Penetapan Peringkat Faktor Permodalan

\begin{tabular}{|c|l|l|}
\hline Peringkat & Keterangan & \multicolumn{1}{|c|}{ Kriteria } \\
\hline 1 & Sangat Sehat & $\begin{array}{l}\text { Rasio KPMM lebih tinggi sangat signifikan } \\
\text { dibandingkan dengan rasio KPMM yang } \\
\text { ditetapkandalam ketentuan (KPMM }>15 \%)\end{array}$ \\
\hline 2 & Sehat & $\begin{array}{l}\text { Rasio KPMM lebih tinggi cukup signifikan } \\
\text { dibandingkan dengan rasio KPMM yang ditetap } \\
\text { kan dalam ketentuan (9\%< KPMM } \leq 15 \%) .\end{array}$ \\
\hline 3 & Cukup Sehat & $\begin{array}{l}\text { Rasio KPMM lebih tinggi secara marjinal } \\
\text { dibandingkan dengan rasio KPMM yang ditetap } \\
\text { kan dalam ketentuan (8\% < KPMM } \leq 9 \%) .\end{array}$ \\
\hline
\end{tabular}




\begin{tabular}{|c|l|l|}
\hline 4 & Kurang Sehat & $\begin{array}{l}\text { Rasio KPMM di bawah ketentuan yang berlaku } \\
(\text { KPMM } \leq 8 \%) .\end{array}$ \\
\hline 5 & Tidak Sehat & $\begin{array}{l}\text { Rasio KPMM dibawah ketentuan yang berlaku } \\
\text { dan bank cenderung menjadi tidak solvable } \\
(\text { KPMM } \leq 8 \%) .\end{array}$ \\
\hline
\end{tabular}

Sumber : Surat Edaran Bank Indonesia

Peringkat komposit dikategorikan sebagai berikut :

1) Peringkat Komposit 1 (PK-1), mencerminkan kondisi bank yang secara umum sangat sehat sehingga dinilai sangat mampu menghadapi pengaruh negatif yang signifikan dari kondisi bisnis dan faktor eksternal lainnya.

2) Peringkat Komposit 2 (PK-2), mencerminkan kondisi bank yang secara umum sehat sehingga dinilai sangat mampu menghadapi pengaruh negatif yang signifikan dari perubahan kondisi bisnis dan faktor eksternal lainnya.

3) Peringkat Komposit 3 (PK-3), mencerminkan kondisi bank yang secara umum cukup sehat sehingga dinilai sangat mampu menghadapi pengaruh negatif yang signifikan dari perubahan kondisi bisnis dan faktor eksternal lainnya.

4) Peringkat Komposit 4 (PK-4), mencerminkan kondisi bank yang secara umum kurang sehat sehingga dinilai sangat mampu menghadapi pengaruh negatif yang signifikan dari perubahan kondisi bisnis dan faktor eksternal lainnya.

5) Peringkat Komposit 5 (PK-5), mencerminkan kondisi bank yang secara umum tidak sehat sehingga dinilai sangat tidak mampu menghadapi pengaruh negatif yang signifikan dari perubahan kondisi bisnis dan faktor internal lainnya.

Penilaian Tingkat Kesehatan Bank sangat penting untuk mempertahankan kepercayaan dari masyarakat dan hanya bank-bank yang benar-benar sehat saja yang dapat melayani masyarakat. Peraturan tentang penilaian kesehatan bank terdapat pada Peraturan Bank Indonesia No. 13/1/PBI/2011 dan SE No. 13/24/ DPNP tanggal 25 Oktober 2011 yang menjadi indicator adalah RGEC yang terdiri dari Risk atau risiko (R), Good Corporate Governance (G), Earnings (E) dan Capital (C) dan penilaiaan menggunakan skala 1 sampai 5 semakin kecil poin yang diterima itu menandakan kesehatan bank semakin baik. RGEC sebagai indikator yang terdiri dari :

\section{Risk profile}

Dengan menghitung rasio Non Performing Loan:

$$
\mathrm{NPL}=\frac{\text { Kredit Bermasalah }}{\text { Total Kredit }} \times 100 \%
$$

Dengan menghitung rasio-rasio sebagai berikut:

Loan to Deposit Ratio (LDR)

$$
L D R=\frac{\text { Total Kredit }}{\text { Dana Pihak Ketiga }} \times 100 \%
$$

Penilaian terhadap resiko terbagi menjadi 8 bagian yaitu:

a. Risiko kredit 
Risiko pinjaman tidak kembali sesuai dengan kontrak, seperti penundaan, pengurangan pembayaran suku bunga dan pinjaman pokonya, atau tidak membayar pinjamannya sama sekali.

b. Risiko pasar

Suatu risiko yang timbul karena menurunnya nilai suatu investasi karena pergerakan pada faktor-faktor pasar.

c. Risiko likuiditas

Risiko kekurangan likuiditas terjadi karena adanya rush moneypenarikan dana secara serentak yang dapat mengakibatkan kebangkrutan bank.

d. Risiko opersional

Risiko kerugian yang diakibatkan oleh kegagalan atau tidak memadainya proses internal, manusia dan sistem, atau sebagai akibat dari kejadian eksternal.

e. Risiko hukum

Risiko dari ketidakpastian tindakan atau tuntutan atau ketidakpastian dari pelaksanaan atau interpretasi dari kontrak, hukum atau peraturan.

f. Risiko stratejik

Risiko yang disebabkan oleh adanya penetapan dan pelaksanaan strategi bank yang tidak tepat, pengambilan keputusan bisnis yang tidak tepat atau kurang responsifnya bank terhadap perubahan eksternal.

g. Risiko kepatuhan

Risiko yang disebabkan oleh ketidakpatuhan suatu bank untuk melaksanakan perundang-undangan dan ketentuan lain yang berlaku, dan

h. Risiko reputasi

Risiko akibat menurunnya tingkat kepercayaan stakeholder yang bersumber dari persepsi negatif terhadap bank. Masing-masing bagian dibagi lagi menjadi 2 bagian yaitu tingkat risiko inheren dan kualitas penerapan manajemen risiko. Sehingga penilaian untuk resiko terdapat 16 penilaian. Meninjau tingkat risiko terbagi atas 5 tingkat. Semakin kecil poin yang diterima maka kesehatan bank dari sisi risiko tersebut semakin baik.

\section{Good Corporate Governance}

Good Corpotrate Governance (GCG) ditinjau dari sisi pemenuhan prinsipprinsip GCG. GCG mencerminkan bagian manajemen dari CAMELS namun telah disempurnakan. Bank memperhitungkan dampak GCG perusahaan pada kinerja GCG bank dengan mempertimbangkan signifikan dan materialitas perusahaan anak dan atau signifikasi kelemahan GCG perusahaan anak.

\section{Earning}

Earning adalah salah satu penilaian kesehatan bank dari sisi rentabilitas. Indikator penilaian rentabilitas adalah ROA (Return On Assets), komponen laba actual terhadap proyeksi anggaran dan kemampuan komponen laba dalam meningkatkan permodalan. Karaktristik bank dari sisi rentabilitas adalah kinerja bank dalam menghasilkan laba, kestabilan komponen-komponen yang 
mendukung core earning, dan kemampuan laba dalam meningkatkan permodalan dan prospek laba di masa depan.

Penilaian terhadap faktor earnings didasarkan pada dua rasio yaitu:

Return on Assets (ROA)

$$
\text { ROA }=\frac{\text { Laba Sebelum Pajak }}{\text { Total Aset }} \times 100
$$

\section{Capital}

Capital atau permodalan memiliki indikator antara lain rasio kecukupan modal dan kecukupan modal bank untuk mengantisipasi potensi kerugian sesuai profil risiko yang disertai dengan pengelolaan permodalanyang sangat kuat sesuai dengan karakteristik, skala usaha dan kompleksitas usaha bank.

Dengan menghitung rasio Capital Adequacy Ratio (CAR) :

Modal Bank

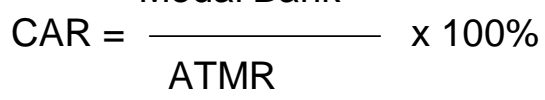

\section{HASIL ANALISA DAN PEMBAHASAN}

\section{A. Hasil}

Penilaian kesehatan bank merupakan penilaian terhadap kemampuan bank dalam menjalankan kegiatan operasional perbankan secara normal dan kemampuan bank dalam memenuhi kewajibannya. Penilaian kesehatan bank sangat penting untuk mempertahankan kepercayaan dari masyarakat dan hanya bank-bank yang benarbenar sehat saja yang dapat melayani masyarakat. Penilaian kesehatan bank dilakukan dengan menilai beberapa faktor yang indikator sehat atau tidaknya suatu bank. Berdasarkan Peraturan Bank Indonesia No. 13/1/PBI/2011 dan SE No. 13/ 24/ DPNP tanggal 25 Oktober 2011 tentang Sistem Penilaian Tingkat Kesehatan Bank Umum, Penilaian kesehatan bank meliputi faktor-faktor sebagai berikut :

1. Risiko (Risk)

Tabel 4.3 : NPL Periode 2013-2017 (Dalam Jutaan Rupiah)

\begin{tabular}{|c|c|c|c|}
\hline NPL & Kredit Bermasalah & Total Kredit & Rasio \% \\
\hline 2013 & $5,421,043$ & $250,637,843$ & $2,16 \%$ \\
\hline 2014 & $5,436,740$ & $277,622,281$ & $1,96 \%$ \\
\hline 2015 & $8,709,610$ & $326,105,149$ & $2,67 \%$ \\
\hline 2016 & $11,644,275$ & $393,275,392$ & $2,96 \%$ \\
\hline 2017 & $10,097,575$ & 441,313566 & $2,29 \%$ \\
\hline
\end{tabular}

Sumber : Data diolah peneliti (2018)

Profil risiko kredit PT Bank Negara Indonesia (Persero) Tbk diukur menggunakan NPL pada tahun 2013 menunjukkan persentase 2,16\%, pada 2014 mengalami kenaikan $1,96 \%$ dikarenakan penurunan pada kredit bermasalah tetapi pada tahun 2015 kembali mengalami penurunan dan menunjukkan persentase $2,67 \%$ yang disebabkan pembayaran kredit bermasalah meningkat. Pada tahun selanjutnya yaitu pada tahun 2016 NPL menunjukkan persentase 2,96\% yang berarti mengalami penurunan kembali dari tahun sebelumnya sekitar $2,67 \%$ yang disebabkan oleh meningkatnya kredit bermasalah dan pada akhir tahun 2017 mengalami kenaikan menunjukan presentase 2,29\% dikarenakan penurunan kredit bermasalah. 
Tabel 4.4 : Bobot PK Komponen NPL (Non Performing Loan)

\begin{tabular}{|c|c|c|c|c|}
\hline Periode & NPL & Kriteria & Peringkat & Keterangan \\
\hline $\mathbf{2 0 1 3}$ & $2,16 \%$ & $2 \%-3,5 \%$ & 2 & Sehat \\
\hline $\mathbf{2 0 1 4}$ & $1,96 \%$ & $2 \%-3,5 \%$ & 1 & Sangat Sehat \\
\hline $\mathbf{2 0 1 5}$ & $2,67 \%$ & $2 \%-3,5 \%$ & 2 & Sehat \\
\hline $\mathbf{2 0 1 6}$ & $2,96 \%$ & $2 \%-3,5 \%$ & 2 & Sehat \\
\hline $\mathbf{2 0 1 7}$ & $2,29 \%$ & $2 \%-3,5 \%$ & 2 & Sehat \\
\hline
\end{tabular}

Sumber : Data diolah peneliti (2018)

\section{Risiko Likuiditas}

1) LDR (Loan to Deposit Ratio)

Tabel 4.5 : LDR Periode 2013-2017 PT. Bank Negara Indonesia (Persero) Tbk

(Dalam Milliaran Rupiah)

\begin{tabular}{|c|c|c|c|}
\hline Periode & Total Kredit & Dana Pihak Ketiga & Rasio \% \\
\hline $\mathbf{2 0 1 3}$ & 250,638 & 282,740 & $88,65 \%$ \\
\hline $\mathbf{2 0 1 4}$ & 277,623 & 300,625 & $92,35 \%$ \\
\hline $\mathbf{2 0 1 5}$ & 326,105 & 353,937 & $92,14 \%$ \\
\hline $\mathbf{2 0 1 6}$ & 393,275 & 415,543 & $94,64 \%$ \\
\hline $\mathbf{2 0 1 7}$ & 441,314 & 492,748 & $89,56 \%$ \\
\hline
\end{tabular}

Sumber : Data diolah peneliti (2018)

Profil risiko likuiditas PT Bank Negara Indonesia (Persero) Tbk diukur menggunakan LDR pada tahun 2013 menunjukkan persentase 88,65\% dapat dikatakan cukup sehat dimana pada tahun tersebut karena rendahnya kredit bermasalah di neraca perbankan. Pada tahun 2014 mengalami penurunan dikarenakan bertambah dana pihak ketiga pada tahun tersebut dan menunjukkan persentase LDR sebesar 92,35\%. Selanjutnya, Pada tahun 2015 mengalami peningkatan walau tidak signifikan dan menunjukkan persentase $92,14 \%$ yang dikarenakan perbandingan antara jumlah kredit yang disalurkan terhadap jumlah dana yang dihimpun dari pihak ketiga hampir seimbang. Pada tahun 2016 LDR menunjukkan persentase 94,64\% yang berarti mengalami penurunan dari tahun sebelumnya sekitar 92,14\% akibat banyak kredit macet dan pada tahun 2017 LDR PT Bank Negara Indonesia (Persero) Tbk menunjukkan persentase $89,56 \%$ terjadi kenaikan signifikan dikarenakan kredit lancar.

Tabel 4.6 : Bobot PK Komponen LDR (Loan to Deposit Ratio)

\begin{tabular}{|c|c|c|c|c|}
\hline Periode & LDR & Kriteria & Peringkat & Keterangan \\
\hline $\mathbf{2 0 1 3}$ & $88,65 \%$ & $85 \%-<100 \%$ & 3 & Cukup Sehat \\
\hline $\mathbf{2 0 1 4}$ & $92,35 \%$ & $85 \%-<100 \%$ & 3 & Cukup Sehat \\
\hline $\mathbf{2 0 1 5}$ & $92,14 \%$ & $85 \%-<100 \%$ & 3 & Cukup Sehat \\
\hline $\mathbf{2 0 1 6}$ & $94,64 \%$ & $85 \%-<100 \%$ & 3 & Cukup Sehat \\
\hline $\mathbf{2 0 1 7}$ & $89,56 \%$ & $85 \%-<100 \%$ & 3 & Cukup Sehat \\
\hline
\end{tabular}

Sumber : Data diolah peneliti (2018)

\section{Good Corporate Governance}

Tingkat kesehatan Bank mencerminkan hasil penilaian kondisi Perseroan yang dilakukan terhadap risiko dan kinerja Bank yang dapat dilihat dari peringkat akhirhasil 
penilaian berdasarkan Peraturan Bank Indonesia No.13/1/PBI/2011 Tentang Penilaian Tingkat Kesehatan Bank Umum dengan menggunakan pendekatan risiko (Risk - based bank rating) yang mencakup 4 faktor sebagai berikut :
a. Profil Risiko (Risk Profile)
b. Good Corporate Governance
c. Rentabilitas (Earnings)
d. Permodalan (Capital)

Hasil Self Assessment di tahun 2013 Berdasarkan hasil penilaian sendiri terhadap 11 kriteria penilaian Good Coporate Governance tahun 2013, Bank panin berada pada peringkat 2 atau keterangan Baik. Penilaian tersebut diperoleh berdasarkan analisis yang dilakukan terhadap seluruh kriteria/ indikator penilaian GCG yang terdiri dari Governance Structure, Governance Process dan Governance Outcome. BNI mendapatkan penghargaan Most Trusted Company Based on Investors and Analyst's Assesment Survey pada Good Corporate Governance Award 2013, Most Trusted Company Based on Corporate Governance Index (CGPI) pada Good Corporate Governance Award 2013, Penghargaan sebagai The Best Bank in Indonesia in Developing Good Corporate Governance (GCG) dari Asiamoney Magazine.

Di tahun 2014 Hasil Self Assessment pelaksanaan Good Corporate Governance (GCG) pada BNI posisi semester I dan II 2014 berada pada peringkat 2 yang mencerminkan Manajemen Bank telah melakukan penerapan

Di tahun 2015, BNI telah melaksanakan self assessment atas pelaksanaan prinsip-prinsip GCG yang diadakan secara rutin paling kurang setiap semester untuk posisi akhir bulan Juni dan Desember dan telah memberikan hasil stabil yaitu di peringkat 2. BNI juga mendapatkan The Best State Owned Enterprise dan Top 50 Public Listed Companies dalam acara Good Corporate Governance Award yang diselenggarakan Indonesia Institute for Corporate Directorship (IICD). Melaksanakan praktik-praktik good corporate governance yang baik serta lebih transparan dan jujur dalam menyampaikan informasi publik. Memperoleh Penghargaan Most Organized Investor Relations, Strongest Adherence to Corporate Governance and Most Consistent Dividend Policy 2015 dari Alpha Southeast Asia. Memperoleh predikat EXCELLENT dari Indonesia Good Corporate Governance Award 2015, majalah Economic Review 2015. Dalam pengelolaan perusahaan, BNI senantiasa mengikuti praktik Good Corporate Governance (GCG) terbaik. Peningkatan praktik GCG di BNI di tahun 2015 tidak terlepas dari komitmen segenap insan BNI untuk melaksanakan prinsip-prinsip GCG sebagai landasan dalam menjalankan bisnis Bank, yang meliputi Transparansi, Akuntabilitas, Responsibilitas, Independensi, dan Kewajaran (TARIK). Dalam menjalankan tugas dan tanggung jawabnya, BNI memiliki kode etik BNI yang merupakan pedoman internal Perusahaan yang berisikan sistem nilai, etika bisnis, etika kerja, komitmen, serta penegakan terhadap peraturanperaturan Perusahaan yang berlaku bagi seluruh insan BNI dalam menjalankan bisnis dan aktivitas lainnya, serta dalam berinteraksi dengan para pemangku kepentingan.

Pada tahun 2016 Dalam rangka evaluasi penerapan GCG, Perseroan melaksanakan GCG Assessment yang dilaksanakan secara periodik dan konsisten setiap tahun yang terdiri dari Self Assessment sesuai ketentuan Bl/ OJK dan Third Party Assessment. Dasar pelaksanaan self assessment adalah POJK No. 55/POJK.03/2016 
tentang penerapan Tata Kelola Bagi Bank Umum. Hasil pelaksanaan self assessment di tahun 2016 menunjukkan nilai komposit 2 (dua) yang mencerminkan Manajemen Bank telah melakukan penerapan GCG yang secara umum BAIK. Third party assessment melalui kegiatan Corporate Governance Perception Index (CGPI) yang diadakan oleh The Indonesian Institute for Corporate Governance (IICG) dan Asean CG Scorecard (ACGS) yang dilaksanakan oleh IICD (Indonesian Institute for Corporate Directorship). Hasil penilaian CGPI menunjukkan bahwa BNI mendapatkan predikat Sangat Terpercaya (Most Trusted). Sedangkan hasil penilaian yang dilakukan terhadap praktik GCG BNI berdasarkan prinsip-prinsip yang diatur dalam ASEAN Corporate Governance Scorecard yang dilaksanakan pada tahun 2016, BNI mendapatkan predikat "GOOD".

Hasil self assessment pelaksanaan GCG PT Bank Negara Indonesia (Persero) Tbk periode 2013-2017 ditetapkan berada pada peringkat 2 dimana mencerminkan manajemen bank telah melakukan penerapan Good Corporate Governance yang secara umum baik. Hal ini tercermin dari governance structure, governance process, dan governance outcome yang memadai sesuai dengan ketentuan yang berlaku, walaupun masih memiliki kelemahan tetapi secara umum kelemahan tersebut dapat diselesaikan dengan tindakan normal oleh manajemen Bank.

3. Rentabilitas (Earnings)

Return on Assets (ROA) :

$$
\text { ROA }=\frac{\text { Laba Sebelum Pajak }}{\text { Total Aset }} \times 100
$$

Tabel 4.7 : PT. Bank Negara Indonesia (Persero) Tbk ROA Periode 2013-2017

\begin{tabular}{|c|c|c|c|}
\hline \multicolumn{2}{|c|}{ (Dalam Jutaan Rupiah) } \\
\hline Periode & $\begin{array}{c}\text { Laba Sebelum } \\
\text { Pajak }\end{array}$ & Total Aset & Rasio \% \\
\hline $\mathbf{2 0 1 3}$ & $11,278,165$ & $386,654,815$ & $2,92 \%$ \\
\hline $\mathbf{2 0 1 4}$ & $13,524,310$ & $416,573,708$ & $3,25 \%$ \\
\hline $\mathbf{2 0 1 5}$ & $11,466,148$ & $508,595,288$ & $2,25 \%$ \\
\hline $\mathbf{2 0 1 6}$ & $14,302,905$ & $603,031,880$ & $2,37 \%$ \\
\hline $\mathbf{2 0 1 7}$ & $17,165,387$ & $709,330,084$ & $2,42 \%$ \\
\hline
\end{tabular}

Sumber : Data diolah peneliti (2018)

Rentabilitas PT Bank Negara Indonesia (Persero) Tbk diukur menggunakan ROA pada tahun 2013 menunjukkan persentase 2,92\%. Pada tahun 2014 mengalami kenaikan dikarenakan bertambahnya laba sebelum pajak dan menunjukkan persentase 3,25\%. Pada tahun 2015 ROA PT Negara Indonesia Tbk juga mengalami penurunan dikarenakan menurunnya laba sebelum pajak yang tidak diimbangi dengan peningkatan aktiva dan menunjukkan persentase $2,25 \%$. Pada tahun selanjutnya yakni 2016 , ROA menunjukkan sedikit kenaikan dari tahun sebelumnya walaupun tidak terlalu signifikan yakni $2,37 \%$ yang berarti $0,12 \%$ persentase kenaikan dari tahun sebelumnya. Pada tahun 2017, ROA PT Bank Negara Indonesia (Persero) Tbk mengalami kenaikan dan menunjukkan persentase 2,42\% dikarenakan laba sebelum pajak pada tahun 2016 mengalami kenaikan yang signifikan dari tahun sebelumnya. 
Tabel 4.8 : Bobot PK Komponen ROA (Return on Assets)

\begin{tabular}{|c|c|c|c|c|}
\hline Periode & ROA & Kriteria & Peringkat & Keterangan \\
\hline $\mathbf{2 0 1 3}$ & $2,92 \%$ & $2 \%>$ ROA & 1 & Sangat Sehat \\
\hline $\mathbf{2 0 1 4}$ & $3,25 \%$ & $2 \%>$ ROA & 1 & Sangat Sehat \\
\hline $\mathbf{2 0 1 5}$ & $2,25 \%$ & $2 \%>$ ROA & 1 & Sangat Sehat \\
\hline $\mathbf{2 0 1 6}$ & $2,37 \%$ & $2 \%>$ ROA & 1 & Sangat Sehat \\
\hline $\mathbf{2 0 1 7}$ & $2,42 \%$ & $2 \%>$ ROA & 1 & Sangat Sehat \\
\hline
\end{tabular}

Sumber : Data diolah peneliti (2018)

\section{Permodalan (Capital)}

Penilaian terhadap faktor permodalan (Capital) meliputi penilaian terhadap tingkat kecukupan permodalan dan pengelolaan permodalan. Rasio untuk menilai permodalan ini adalah Capital AdequacyRatio (CAR).

Tabel 4.9 : CAR Periode 2013-2017 PT. Bank Negara Indonesia Tbk.

(Dalam Milliaran Rupiah)

\begin{tabular}{|c|c|c|c|}
\hline Periode & Modal Bank & ATMR & Rasio \% \\
\hline $\mathbf{2 0 1 3}$ & 43,563 & 251,142 & $17.35 \%$ \\
\hline $\mathbf{2 0 1 4}$ & 50,352 & 268,430 & $18.76 \%$ \\
\hline $\mathbf{2 0 1 5}$ & 73,799 & 329,343 & $22.41 \%$ \\
\hline $\mathbf{2 0 1 6}$ & 84,278 & 378,716 & $22.25 \%$ \\
\hline $\mathbf{2 0 1 7}$ & 95,307 & 450,706 & $21.15 \%$ \\
\hline
\end{tabular}

Sumber : Data diolah peneliti (2018)

Permodalan PT Bank Negara Indonesia (Persero) Tbk diukur menggunakan CAR pada tahun 2013 menunjukkan persentase 17,36\%. Pada tahun 2014 CAR PT Bank Negara Indonesia (Persero) Tbk mengalami kenaikan dikarenakan bertambahnya total modal yang dibarengi dengan jumlah ATMR dan menunjukkan persentase 18,76\%. Pada tahun 2015 CAR PT Bank Negara Indonesia Tbk juga mengalami kenaikan yang tidak signifikan dan menunjukkan persentase $22,41 \%$ yang dikarenakan kenaikan aktiva yang didukung oleh kenaikan modal. Pada tahun selanjutnya yakni 2016, CAR menunjukkan sedikit penurunan dari tahun sebelumnya walaupun tidak terlalu signifikan yakni $22,25 \%$. Pada tahun 2017, CAR PT Bank Negara Indonesia Tbk mengalami penurunan kembali dan menunjukkan persentase $21,15 \%$ dikarenakan terjadinya kenaikan aktiva tidak di imbangi dengan modal.

Tabel 4.10 : Bobot PK Komponen CAR (Capital Adequacy Ratio)

\begin{tabular}{|c|c|c|c|c|}
\hline Periode & CAR & Kriteria & Peringkat & Keterangan \\
\hline $\mathbf{2 0 1 3}$ & $17,35 \%$ & $12 \%>$ CAR & 1 & Sangat Sehat \\
\hline $\mathbf{2 0 1 4}$ & $18,76 \%$ & $12 \%>$ CAR & 1 & Sangat Sehat \\
\hline $\mathbf{2 0 1 5}$ & $22,41 \%$ & $12 \%>$ CAR & 1 & Sangat Sehat \\
\hline $\mathbf{2 0 1 6}$ & $22,25 \%$ & $12 \%>$ CAR & 1 & Sangat Sehat \\
\hline $\mathbf{2 0 1 7}$ & $21,15 \%$ & $12 \%>$ CAR & 1 & Sangat Sehat \\
\hline
\end{tabular}

Sumber : Data diolah peneliti (2018) 


\section{B. Rangkuman Pembahasan}

Tabel 4.11 : PT Bank Negara Indonesia (Persero) Tbk

Rangkuman Periode 2013-2017 Penilaian Kesehatan Bank

\begin{tabular}{|c|c|c|c|c|c|}
\hline Komponen Faktor & Tahun & Rasio & \% Rasio & PK & Keterangan \\
\hline \multirow{10}{*}{ Risk } & \multirow{2}{*}{2013} & NPL & $2,16 \%$ & 2 & Sehat \\
\hline & & LDR & $86,12 \%$ & 3 & Cukup Sehat \\
\hline & \multirow{2}{*}{2014} & NPL & $1,96 \%$ & 1 & Sangat Sehat \\
\hline & & LDR & $89,83 \%$ & 3 & Cukup Sehat \\
\hline & \multirow{2}{*}{2015} & NPL & $2,67 \%$ & 2 & Sehat \\
\hline & & LDR & $89,44 \%$ & 3 & Cukup Sehat \\
\hline & \multirow{2}{*}{2016} & NPL & $2,96 \%$ & 2 & Sehat \\
\hline & & LDR & $91,75 \%$ & 3 & Cukup Sehat \\
\hline & \multirow{2}{*}{2017} & NPL & $2,29 \%$ & 2 & Sehat \\
\hline & & LDR & $86,14 \%$ & 3 & Cukup Sehat \\
\hline \multirow{5}{*}{$\begin{array}{c}\text { Good Corporate } \\
\text { Governance }\end{array}$} & 2013 & GCG & & 2 & Baik \\
\hline & 2014 & GCG & & 2 & Baik \\
\hline & 2015 & GCG & & 2 & Baik \\
\hline & 2016 & GCG & & 2 & Baik \\
\hline & 2017 & GCG & & 2 & Baik \\
\hline \multirow{5}{*}{ Earnings } & 2013 & ROA & $2,92 \%$ & 1 & Sangat Sehat \\
\hline & 2014 & ROA & $3,25 \%$ & 1 & Sangat Sehat \\
\hline & 2015 & ROA & $2,25 \%$ & 1 & Sangat Sehat \\
\hline & 2016 & $\mathrm{ROA}$ & $2,37 \%$ & 1 & Sangat Sehat \\
\hline & 2017 & ROA & $2,42 \%$ & 1 & Sangat Sehat \\
\hline \multirow{5}{*}{ Capital } & 2013 & CAR & $17,35 \%$ & 1 & Sangat Sehat \\
\hline & 2014 & CAR & $18,76 \%$ & 1 & Sangat Sehat \\
\hline & 2015 & CAR & $22,41 \%$ & 1 & Sangat Sehat \\
\hline & 2016 & CAR & $22,25 \%$ & 1 & Sangat Sehat \\
\hline & 2017 & CAR & $21,15 \%$ & 1 & Sangat Sehat \\
\hline
\end{tabular}

Sumber : Data diolah peneliti (2018)

\section{KESIMPULAN \& SARAN}

\section{A. Kesimpulan}

Berdasarkan hasil penelitian dan harus menjawab rumusan masalah berdasarkan analisis yang telah dilakukan maka dapat diambil kesimpulan sebagai berikut :

1. Kesehatan Berdasarkan Risk Profile Bank BNI tahun 2013 sampai 2017 dapat dikatakan "SEHAT" rata- rata berada di kriteria $2 \%<\mathrm{NPL} \leq 5 \%$ mendapatkan PK 2.

2. Kesehatan Berdasarkan Good Corporate Governance Bank BNI tahun 2013 hingga 2017 dapat di simpulkan "SEHAT" setiap tahunnya mendapatkan PK 2.

3. Kesehatan Berdasarkan Earning Bank BNI dari tahun 2013 sampai dengan tahun 2017 secara keseluruhan mendapatkan PK 1 dapat dikatakan "SANGAT SEHAT".

4. Kesehatan Berdasarkan Capital Bank BNI dari tahun 2013 - 2017 dengan keseluruhan CAR mendapatkan PK 1 dapat disimpulkan "SANGAT SEHAT". 
5. Penilaian Tingkat Kesehatan Bank BNI dengan menggunakan metode RGEC ini menunjukkan predikat kesehatan bank tersebut sesuai dengan standar yang telah ditetapkan oleh Bank Indonesia, dapat disimpulkan bahwa Bank BNI "SEHAT" dilihat dari rata-rata penilaian. Tingkat Kesehatan Bank ditinjau dari aspek risk profile, earnings, good corporate governance, dan capital pada Bank Negara Indonesia tahun 2013 - 2017 sehat sehingga dinilai sangat mampu menghadapi pengaruh negatif yang signifikan dari perubahan kondisi bisnis dan faktor eksternal lainnya tercermin dari peringkat faktor-faktor penilaian antara lain profil risiko, rentabilitas, dan permodalan secara umum sangat baik.

\section{B. Saran}

1. Sebagai bank yang dimiliki oleh BUMN sebaiknya Bank Negara Indonesia mampu mempertahankan kesehatan bank pada tahun-tahun berikutnya. Kesehatan bank yang sangat sehat akan meningkatkan kepercayaan masyarakat, nasabah, karyawan pemegang saham, dan juga pihak lainnya.

2. Mempertahankan kesehatan bank untuk tahun-tahun berikutnya tidak hanya berfokus pada laporan keuangan, tetapi Bank Negara Indonesia perlu juga untuk mengembangkan usaha dengan pelayanan yang diberikan lebih aman, mudah, dan juga cepat. Selain itu, pengaruh negatif yang signifikan dari perubahan kondisi bank bisnis dan faktor eksternal lainnya hendaknya menjadi tolak ukur dalam menyusun anggaran tahun berikutnya.

\section{DAFTAR PUSTAKA}

Bank Indonesia. 1968. Peraturan Pemerintah Pengganti Undang-Undang No. 2 tahun 1946 tanggal 5 Juli 1946. Selanjutnya, berdasarkan Undang-Undang No. 17 tahun 1968, BNI ditetapkan menjadi "Bank Negara Indonesia 1946", dan statusnya menjadi Bank Umum Milik Negara. Jakarta : Bank Indonesia. 2011. Peraturan Bank Indonesia (PBI) Nomor 13/1/PBI/2011 tentang penilaian Tingkat Kesehatan Bank, serta Surat Edaran Bank Indonesia Nomor 15/15/DPNP tanggal 29 April 2013 tentang Pelaksanaan GCG bagi Bank Umum. Jakarta : Bank Indonesia.

. 2011. Peraturan Bank Indonesia No. 13/1/PBI/2011 dan SE No. 13/24/ DPNP tanggal 25 Oktober 2011 yang menjadi indicator adalah RGEC yang terdiri dari Risk atau risiko (R), Good Corporate Governance (G), Earnings (E) dan Capital (C). Jakarta : Bank Indonesia.

2011. Peraturan bank Indonesia No. 13/1/PBI/2011 Pasal 7 ayat 2 sebagaimana dimaksud dalam pasal 6 huruf $d$ meliputi penilaian terhadap tingkat kecukupan permodalan dan pengelolaan permodalan. Jakarta : Bank Indonesia.

. 2011. Peraturan Bank Indonesia Nomor 13/1/PBI/2011 tentang Penilaian Tingkat Kesehatan Bank Umum, Bank Indonesia telah menetapkan sistem penilaian Tingkat Kesehatan Bank berbasis risiko menggantikan penilaian CAMELS. Jakarta : Bank Indonesia. 
2012. Berdasarkan ketetapan Bank Indonesia yang disajikan dalam Laporan Pengawasan Bank (2012:36):"governance structure mencakup pelaksanaan tugas dan tanggung jawab Dewan Komisaris dan Dewan Direksi serta kelengkapan dan pelaksanaan tugas komite. Jakarta : Bank Indonesia.

Bank Negara Indonesia. 2013, 2014, 2015, 2016, 2017. Laporan Keuangan Bank Negara Indonesia. Jakarta: Bank Negara Indonesia.

Hantono. 2017. Effect of Capital Adequacy Ratio (CAR), Loan to Deposit Ratio(LDR) And Non Performing Loan (NPL) To Return On Assets (ROA) Listed In Banking In Indonesia Stock Exchange. International Journal of Education and Research. Vol. 5 No. 1 January, pp. 69-80.

Herdiyanti. 2012. Bank dan Lembaga Keuangan Lainnya. Jakarta : Salemba empat.

Ikatan Akuntan Indonesia. 2007. Standar Akuntansi Keuangan per 1 September 2007. Jakarta : Salemba empat.

Kasmir. 2011. Bank dan Perbankan . Jakarta : Rajawali Pers. 2012. Analisis Laporan Keuangan. Cetakan Keenam. Jakarta: PT. Raja Grafindo.

Nur Indriantoro dan Bambang Supomo. 2013. Metodologi Penelitian Bisnis. Yogyakarta : BPFE

Permana. 2012. Analisis Tingkat Kesehatan Bank Berdasarkan Metode CAMELS dan Metode RGEC. Surabaya: Universitas Negeri Surabaya.

Rivai, Veithzal, dkk. 2007. Commercial Bank Management:Manajemen Perbankan dari Teori ke Praktik. Jakarta: PT Raja Grafindo Persada.

Sabir, M. S. et al. 2012. Theoretical Foundation of Business Model and their Building Blocks. Journal of Management Research.

Santoso dan Nuritomo. 2014. Bank dan Lembaga Keuangan Lain. Jakarta: Salemba empat.

Santoso. 2006. Bank dan Lembaga KeuanganLainnya. Jakarta : Salemba empat. Sunarti. 2011. Manajemen Perbankan. Jakarta : Ghalia indonesia. 